\title{
METHODIC OF PERFECTION OF HIGHER PEDAGOGICAL EDUCATIONAL ESTABLISHMENTS GIRL STUDENTS' RHYTHM
}

Kolumbet A.N., Dudorova L.Yu.

Kiev National University of Technology and Design

\begin{abstract}
Purpose: to study influence of methodic of rhythm perfection on girl students' coordination abilities. Material: in the research 264 girl students participated. We assessed individual and collective rhythm, internal and external motor rhythm; rhythm in exercises with musical accompaniment. Results: we have determined that creative motor tasks require variable conditions for their realization. We have proved demand in appropriate criteria for their assessment. It is noted that there is a demand in development of rhythm, considering its main kinds and manifestations, which are formed with some peculiarities. Individual rhythm is determined by activation of attention and its level. It is perfected more successfully rather with stimulated development than with natural. It was found that with age the character of natural progressing of rhythm preserves. Conclusions: it is recommended to develop rhythm in compliance with its kinds and manifestations. Progressing and perfection of rhythm is a long lasted process and shall be realized during all period of girl students' studying. Such approach forms girl students' demand in finding of purposeful motor rhythm in all their new motor actions. It ensures optimality of their fulfillment.
\end{abstract}

Key words: physical education, coordination abilities, rhythm, girl students.

\section{Introduction}

Rhythm is the basis of live systems' functioning. Self regulation of processes, adaptation to environmental changes; preservation of homeostasis are impossible without it, as well as synchronization of physiological processes under influence of physical loads. Motor actions also have certain rhythm: natural alteration of different efforts [2, 16, and 18].

When training physical exercises it is necessary to build theoretical model of rhythmic movements, which would be the content of them. Their visible simplicity, high orderliness in space and time can create an image of excess easiness and simplicity. Actually, for achievement of high results in moving much more time and efforts are spent. Free motor rhythms completely depend on human will and are the highest degree of motor acts' organization.

One of important tasks of physical education is development of strive for beauty and perfectness; search of new ways of effectiveness increase. For this purpose, it is necessary to strive for variable content of trainings; cultivate girl students' demand in everyday physical exercises; teach them to strive for purposeful motor actions and their variability [4, 24, 28, 30-34].

Significance of rhythm (as coordination ability) is determined by the fact that with its help optimal correlation of motor act's different parts is achieved; its continuity and joining are ensured as well as rational distribution of efforts in space and time. This coordination quality requires more attention to its development and perfection.

The problems of coordination qualities' development have always been paid great attention. Researches of a number of authors are devoted to perfection of coordination qualities in youth [7, 9, 14, 15, 18, 25, and 35]. Alongside with it, the authors did not manage to completely elucidate the problem of rhythm development in pedagogic HEEs' girl students.

Hypothesis: we assumed that our research (in the process of long lasted experiment) of rhythm's kinds will permit to mark out its main components, determine its assessment criteria. It will permit to offer renewed methodic of rhythm stimulated perfection in HEEs' girl students.

The purpose of the research is analysis of influence of rhythm stimulated perfection methodic on pedagogic HEEs' girl students' coordination abilities.

\section{Material and methods}

(c) Kolumbet A.N., Dudorova L.Yu., 2016 doi:10.15561/20755279.2016.0301 
Participants: in the research $2641^{\text {st }}-3^{\text {rd }}$ year girl students (17-21 years' age) of Chernigov national pedagogic university, named after T.G. Shevchenko and Kiev university, named after Boris Grinchenko, participated. All girl students belonged to main health group.

Procedure: the research was fulfilled during 2008-2010. Rhythm indicators were determined by every kind at the beginning, in the middle and at the end of academic year. We used five tests, offered by the authors earlier $[13 ; 19]$.

Individual rhythm was assessed with test 1 . When walking by lunges foot drops on the floor with certain accent from toe to full foot. The sound of foot's contact with floor shall be equal by strength and uniform by duration. The assessment of motor rhythm was as follows: 5 points - leg drops on toe without sound and with accent - from toe on all foot, through equal periods of time. Amplitude of movements shall be equal, carriage good, actions shall be free and expressive. 4 points: there is certain tension and stiffness, but movements are uniform and accented. 3 points - movements are accented with good amplitude with one or two disorders in steps' uniformity.

Collective rhythm was assessed with the help of test 2. Girl student stood facing group of 3-5 persons, who fulfilled general exercises. Then, synchronously with other girl students she reproduced the same movements. We assessed degree of coincidence by direction, temp, amplitude, expressiveness. 5 points meant complete coincidence by all main parameters; actions are expressive and accurate; 4 points - actions coincide by direction, temp and amplitude, but are stiff and not expressive; 3 points - movements coincide in general by main parameters with two-three failures in temps and direction.

External rhythm of movements was assessed with the help of test 3 . The tested copied the showed by teacher exercise: walking with forward rising of straight leg (up to horizontal level), moving hands aside (at shoulder level). It is necessary to keep the picture of movement, its form, amplitude, dynamic. We assessed the coincidence of the fulfilled exercise with the task. 5 points mean complete coincidence: leg is straight, risen up to horizontal level with stretched toe, arms are straight, moved accurately aside, making straight line, head is up, back is straightened; 4 points - leg is in horizontal position but toe is not sufficiently stretched; hands are moved exactly aside but head is a little dropped; 3 points mean leg positioned lower than horizontal position, hands are moved aside not accurately, movements are stiffed.

Internal rhythm was assessed with test 4 . The tested girl students fulfilled the showed by teacher dance movement: forward waltz step with forward and aside hands' moving, radiating gay and merry mood. We assessed coincidence of movement's external form with radiated mood: 5 points - movements are correct by form and smooth, eyes follows hands' movement, expression of face is happy; 4 points - movements are correct by form and character of fulfillment, smile is stiffed; 3 points - movements are correct by direction and amplitude, but there are no emotions.

Rhythm in exercises with musical accompaniment was assessed with test 5. Having listened to musical fragment, the tested girl students fulfilled exercise in compliance with its character. We assessed compliance of character of movement with content of musical fragment: 5 points meant complete coincidence of movements with character of musical accompaniment (march sounds - the tested fulfills drill step; waltz sounds - wide steps' walking or lunges; polka sounds - jumps by both legs and etc.); 4 points - insignificant coincidence of movements with character of musical accompaniment; movements are chosen correctly but do not coincide sufficiently by amplitude and temp. 3 points were given for one or two incomplete coincidence with character of melody: jumps under march music; run under waltz melody.

Statistical analysis: for processing of the research's results we used commonly accepted methods of mathematical statistic. For each of the tested indicators we calculated mean values and mean square deviation. Assessment of differences' confidence was fulfilled by Student's t-criterion at $1 \%$ and $5 \%$ significance levels. We calculated increment of the studied indicators. Increment temps was calculated by formula of S. Broudy:

$$
\mathrm{W}=\mathrm{V}_{2}-\mathrm{V}_{1} / 0,5 \times\left(\mathrm{V}_{2}+\mathrm{V}_{1}\right) \times 100 \%
$$

where: V1 and V2 - accordingly, initial and final results in control testing. 
In fulfillment of complex pedagogic and biological examinations, in which girl students participated, we observed legislation of Ukraine about health protection, the Declaration of Helsinki 2000, Directive №86/609 of European community on participation of people in medical - biological researches.

\section{Results}

Methodic of stimulated rhythm's development implied introduction of motor tasks in every training by all rhythm's kinds: activation of attention, training of motor memory, distribution and applying of efforts, orientation in space and time and ability to general actions. Depending on type of training (its tasks, purpose), special exercises were given to girl students in warming up (main and finalizing) parts, in different sequence and scope. These exercises were of different complexity. For example light athletics training had subject: run in various directions and with different speed, throwing of small ball for distance. The task was to familiarize with peculiarities of runs with changing of direction and speed; to perfect technique of small ball throwing for distance from the spot. Warming up part included exercises for activation of attention as necessary condition of rhythm's perfection: in walking first and third steps were to be marked with claps; after every third step - right hand rising with left on the waist; after five steps - turn by $360^{\circ}$; determination and memorizing of distance between steps in run and walking; memorizing of efforts in walking, calm run and with acceleration, Moving in column the tested shall fulfill general and warming up exercises synchronously with leading girl student.

In main part of training girl students were offered warming up and special exercises for main rhythm's kinds development: in run by right side of the gym every fifth step was fulfilled with turn to the right and every tenth step - with turn to the left by $180^{\circ}$; in run by left side of gym left leg was put with accent. Steps should have been equal by amplitude with uniform speed; in diagonal running - double acceleration at the beginning (10-12 $\mathrm{m}$ ) and in the middle of distance. The offered run tasks had clear rhythm and required certain fitness. That is why girl students were permitted to fulfill these exercises independently in free time.

For mastering of throw rhythm of small ball throwing for distance we used motor actions for activation of attention: visual inspection of place for ball throw, noting of some guide points; compare different by value efforts for preparatory movements (dropping of hand with ball, moving hand backward - upward) and main motor action (throw); concentration of attention on difference in applied efforts for fulfillment of main part of ball throw.

Development of motor memory was realized with the help of the following tasks: count and remember quantity of run steps in right and left sides of gym with accented putting of right and left legs. Determine the quantity of run steps in first and second accelerations in diagonal run and all additional steps before and after acceleration; remember the value of efforts in run with changing of direction and speed and in period of acceleration.

For training of rhythm of applying and distribution of efforts the following exercises were envisaged: run with turns to the right and to the left by $360^{\circ}$, run with back forward, prolongation of run step up to maximal amplitude, run with shortened steps and many other.

For perfection of small ball throwing girl students also fulfilled a number of movements: throw behind marked line from stance "on one knee", from sitting position with straightened legs, with closed eyes, with quarter of strength, with half of strength and so on.

For better orientation in space girl students fulfill run by the right and left sides of gym within definite corridors (width 1-1.5 m), marked with chalk or paper strips. Having remembered the width of corridor and steps' amplitude, they were to repeat the task without additional guide points. Having determined speed of 10 meters' segment run by diagonal they were to keep it at longer (20 meters') segment.

When throwing small bal for distance the girl students were offered: a) remember ball's trajectory in the best attempt and repeat it several times; b) determine amplitude of additional and main movements, when throwing, compare throw distance with different arm's amplitude and additional step forward; c) compare different feelings, when throwing ball in gym and outdoors.

Training and perfection of collective rhythm (ability to collective actions) was realized in the process of sports game at the end of main part of training. Besides, girl students mastered Greek folk dance "Sirtaki" with accented rhythmic movements, which are fulfilled first slowly and then - with gradual acceleration. For better feeling of mutual actions girl students positioned their hands on shoulders of each other. In finalizing part of training there were exercises for attention, fixing of motor memory and other: a) walking with accented foot putting 
on toe ("acute" step), with arms' movement (rising on tip toes - hands up, when dropping on full feet - hands down), hands behind head with keeping straight carriage; b) walk, rolling from heel to toes with accent on vertical position in upper point (position - on toes), arms aside with palms upward and other.

By the end of first year training for rhythm's development and perfection some results became obvious (see table 1). Girl students became able to fulfill exercises with higher amplitude, correctly find required accents. Culture of movements improved. Materials of the research point at demand in development of rhythm, considering its main kinds and manifestations, which are formed with some peculiarities. For example, individual rhythm was determined by degree of attention's development and activation. It is perfected more successfully in stimulated development than in natural.

Analysis of rhythm increment by level of motor memory permitted to find that with age the character of rhythm's natural development is preserved. Indicators are gradually improved. In stimulated formation of this rhythm's kind it was registered that experimental trainings favorably influenced on increment temps. Girl students reproduce by form a lot of motor actions with rather high accuracy. In their age, for mastering of motor action's character application of visible patterns is quite sufficient. Systemic fulfillment of different game exercises by girl students with their gradual complication facilitates development of motor memory.

Some peculiarities of rhythm increment were observed when fulfilling collective actions (collective rhythm). This kind of rhythm is connected with some specific requirements. They include ability to distribute very accurately muscular efforts, orienting on movements of team members. The pre-set amplitude requires accuracy of exercise's fulfillment by space characteristics. Targeted perfection facilitated better increment of indicators; the offered motor tasks did not require significant strength. With game or competition methods they facilitated more successful transformation of motor actions' individual rhythm into collective.

Analysis of data on formation of rhythm in exercises with musical accompaniment showed that natural increment of indicators has tendency to improvement with age. Application of stimulated development methodic for this rhythm kind showed the highest increment temps of experimental girl students' indicators.

Table 1. Increment of indicators (\%) of different kinds of rhythm

\begin{tabular}{|c|c|c|c|c|c|c|c|}
\hline \multirow[t]{2}{*}{ № } & \multirow[t]{2}{*}{ Tests } & \multirow{2}{*}{$\begin{array}{l}\text { Period of } \\
\text { research }\end{array}$} & \multicolumn{2}{|c|}{ Control group } & \multicolumn{2}{|c|}{$\begin{array}{l}\text { Experimental } \\
\text { group }\end{array}$} & \multirow[t]{2}{*}{$\mathbf{p}$} \\
\hline & & & M & $\pm m$ & $\mathbf{M}$ & $\pm m$ & \\
\hline \multirow[t]{2}{*}{1} & 2 & 3 & 4 & 5 & 6 & 7 & 8 \\
\hline & & $1^{\text {st }}$ year & 2.28 & 0.18 & 8.14 & 0.26 & $<0.05$ \\
\hline \multirow[t]{3}{*}{1} & Individual rhythm & $2^{\text {nd }}$ year & 4.62 & 0.20 & 10.22 & 0.36 & $<0.05$ \\
\hline & & $3^{\text {rd }}$ year & 3.78 & 0.30 & 11.53 & 0.46 & $<0.05$ \\
\hline & & $1^{\text {st }}$ year & 2.60 & 0.15 & 9.17 & 0.42 & $<0.05$ \\
\hline \multirow[t]{2}{*}{2} & Collective rhythm & $2^{\text {nd }}$ year & 3.05 & 0.15 & 8.95 & 0.40 & $<0.05$ \\
\hline & & $3^{\text {rd }}$ year & 3.31 & 0.26 & 10.56 & 0.45 & $<0.05$ \\
\hline \multirow{3}{*}{3} & \multirow{3}{*}{$\begin{array}{l}\text { Internal and external rhythm of } \\
\text { movements }\end{array}$} & $1^{\text {st }}$ year & 3.40 & 0.14 & 4.00 & 0.26 & $>0.05$ \\
\hline & & $2^{\text {nd }}$ year & 4.00 & 0.31 & 4.78 & 0.27 & $>0.05$ \\
\hline & & $3^{\text {rd }}$ year & 3.74 & 0.28 & 5.15 & 0.27 & $>0.05$ \\
\hline \multirow{3}{*}{4} & & $1^{\text {st }}$ year & 2.63 & 0.09 & 4.57 & 0.27 & $>0.05$ \\
\hline & Rhythm in exercises with & $2^{\text {nd }}$ year & 4.12 & 0.18 & 5.77 & 0.38 & $>0.05$ \\
\hline & & $3^{\text {rd }}$ year & 3.99 & 0.29 & 4.27 & 0.25 & $>0.05$ \\
\hline
\end{tabular}




\section{Discussion}

Man is able to control free motor act, in the base of which there is definite rhythm. In this case we speak about higher level of muscular functioning's organization. In the process of active muscular functioning motor rhythm is generated by motor system itself. With impulses' entering nervous system their transformation occurs. As a result new algorithms of motor actions appear. Main elements of muscular functioning (neuron connections of central nervous system, nervous-muscular apparatus) switch in organized movement of all motor system with definite clear rhythm $[1,10$, and 21].

Functional system ensures reverse afferentation - connection from working organ to regulating nervous centers [11, 20, and 24]. Receptor signal circulates by closed ring from muscular, ligament and tactile receptors in the form of neuron impulses. Simultaneously it fulfills a role of timer and program, determining rhythm.

Information about space-time and space-power characteristics of motor action is conditioned by appearing of certain rhythm. The emerged impulses transform in mechanical movement. Depending on external conditions (age of a trainee, physical fitness, character of motor task and etc.) there happens constant modification of motor program. As a result rational motor team, amplitude, distribution of efforts and optimal rhythm take place [2, 17].

Rhythm conditions required correlation of motor act's separate phases, continuity of muscular functioning during pre-set time, coincidence and amplitude of movements. Physical exercise has certain speed (temp) and regulated distribution of efforts (dynamic). The temp and dynamic of motor act are closely interconnected and influence on each other. It is not possible to voluntarily change temp of run or distribution of efforts. The higher is temp of run for long jump the more efforts are required for their rational distribution in order to create optimal conditions for fulfillment of main motor act $[3,19,28]$. With too high temp of run fulfillment of preparatory actions for push off becomes more difficult. That is why at the last step and the step before last speed is reduced. It permits to more completely realize motor potential. Temp, dynamic and harmony are the main components of rhythm.

Temp is speed of fulfillment of motor act's separate elements. Physiological functions to large extent are determined by speed. The higher it is the stronger muscular load's influence on organism. With insufficient speed training influence is absent as well as positive effects [2, 4, 18].

Dynamic (distribution of efforts in fulfillment of physical exercises) is one more component of rhythm. Motor act consists of several components, which require different muscular efforts. For example, long jump from the sport with push by two legs and arms' waving includes the following preparatory actions: squatting, moving arms backward, re-distribution of muscular-skeletal apparatus's links; then - push forward by two legs with quick arms' waving (main phase is accompanied by maximal muscular efforts), landing and keeping body balance (final phase, in which efforts sharply reduce).

If temp of movements coincides with dynamic of muscular efforts' distribution, then change of many nervous centers and inter-centers relations' functional state take place; conditional reflex activity improves, coincidence of motor and vegetative functions' activity increases. As a result harmony of movements is achieved $[1,9,14,15]$.

Harmony is manifested as more perfect control over body with fulfillment of physical exercises. With coincidence of temp and dynamic less time and efforts are required for motor act with higher movements' amplitude. In this connection in practicing of physical exercises it is necessary to work out individual rhythm. Feeling of lightness of movements, "muscular joy", satisfaction of trainings are important signs of individual rhythm's formation. Without it, it is impossible to cultivate demand in motor functioning, strive for achievement its optimal scope, ensuring required level of health.

The character of rhythm depends on specificity of motor actions. Physical exercises are fulfilled individually and collectively. In cyclic and non cyclic exercises rhythm is different. Rhythm is greatly influenced by musical accompaniment. We can mark out the following main kinds of rhythm, characteristic for motor functioning: individual rhythm; collective rhythm, external rhythm; internal rhythm; rhythm in cyclic physical exercises; rhythm in non cyclic physical exercises and rhythm in exercises with musical accompaniment $[6,15$, $16,22]$.

Different kinds and manifestations of rhythm determine content of methodic of definite motor functioning training. For mastering new physical exercise it is necessary to determine its rhythm; to find principle moment of 
efforts' application (to make program of actions) [2, 5, 8, 12, 23]. With it, rhythm's manifestation depends on a number of factors and is assessed with the help of special criteria [7, 19, 20, 27].

It would not be correct to speak about development and perfection of rhythm in general. It is known that at one or several trainings it is possible to form one or another kind of motor coordination, depending on tasks of training.

\section{Conclusions}

1. Rhythm is a kind of coordination qualities, which has its own kinds and manifestations. With it, its perfection implies usage of various exercises.

2. Creative motor tasks imply different conditions for their realization. For their assessment appropriate criteria are required.

3. Rhythm training shall be in compliance with its kinds and manifestation. It requires appropriate approach to content of the methodic and its perfection.

4. Targeted development of rhythm, considering its kinds and manifestations results in improvement of its indicators with different temps of increment. It positively reflects on girl students' physical fitness.

5. Development and perfection of rhythm is of long term character and shall be realized during all period of girl students' studying at HEE. Such approach forms girl students' demand in finding of purposeful motor rhythm in all new motor actions that ensures optimality of their fulfillment.

\section{Acknowledgements}

The researches have been fulfilled in compliance with scientific program of Chernigov national pedagogic university, named after T.G. Shevchenko physical education faculty by topic "Didactic principles of motor function's formation in persons, who practice physical education and sports" (state registration number 0108U000854).

\section{Conflict of interests}

The authors declare that there is no conflict of interests.

\section{References:}

1. Anokhin PK. Uzlovye voprosy teorii funkcional'noj sistemy [Key problems of functional system theory], Moscow: Science; 1980. (in Russian)

2. Bernshtejn NA. O lovkosti i ee razvitii [On dexterity and its training], Moscow: Physical Culture and Sport; 1991. (in Russian)

3. Bojchenko SD, Karseko EN, Leonov VV, Smotrickij AL. Problemy koncepcii koordinacii i koordinacionnykh sposobnostej $\mathrm{v}$ fizicheskom vospitanii [Problems of coordination and coordination conception in physical education]. Pedagogics, psychology, medical-biological problems of physical training and sports, 2002;2:5355. (in Russian)

4. Bojchenko SD, Karseko EN, Leonov VV, Smotrickij AL. O nekotorykh aspektakh izucheniia koordinacionnykh sposobnostej $\mathrm{v}$ teorii fizicheskogo vospitaniia $\mathrm{i}$ teorii sporta [On some aspects of coordination abilities study in theory of physical education and theory of sports]. Teoriia i praktika fizicheskoj kul'tury, 2003;8:19-22. (in Russian)

5. Bojchenko SD, Ejder E, Iashanina N, Leonov V, Iashanin Ia, Bojchenko T. Koordinacionnye sposobnosti kak veshchestvennye korreliaty effektivnosti obucheniia dvigatel'nym dejstviiam [Coordination abilities as substantial correlates of effectiveness of motor actions' training]. Pedagogics, psychology, medical-biological problems of physical training and sports, 2003;11:39-43. (in Russian)

6. Bryukhanova NA, Bulgakova OV, Mokrova TI, Bogashchenko YA. Determination of possibilities of the use of high-intensive trainings facilities on lessons health aerobics. Physical Education of Students, 2013, vol.2, pp. 25-29. doi:10.6084/m9.figshare. 156376

7. Vlasiuk OO. Vikoristannia elementiv suchasnikh tanciv $i$ khoreografii na zaniattiakh z fizichnogo vikhovannia studentok 17-18 rokiv [Application of modern dances and choreography elements in physical education classes of 17-18 years' age girl students]. Visnik Chernigivs'kogo nacional'nogo pedagogichnogo universitetu. 2012;98(1):93-97. (in Ukrainian)

8. Volkov VL. Rozvitok fizichnikh zdibnostej studentiv u sistemi fizichnoi pidgotovki [Development of students' physical abilities in system of physical training], Kiev: Education Ukraine; 2011. (in Ukrainian) 
9. Gibaeva NN, Liulina NV, Zakharova NV. Osobennosti ispol'zovaniia fitnes programm po fizicheskoj kul'tury studentov [Specific features of fitness programs on students' physical culture application]. Physical Education of Students, 2010;6:16-19. (in Russian)

10. Donskoj DD. Psikhomotornoe edinstvo upravleniia fizicheskimi uprazhneniiami kak dvigatel'nymi dejstviiami (ot «mekhaniki zhivogo» $\mathrm{k}$ psikhobiomekhanike dejstvij [Psycho-motor unity of physical exercises control as motor actions (from mechanic of "alive" to psycho-bio-mechanic of actions)]. Teoriia $i$ praktika fizicheskoj kul'tury, 1994;5-6:23-26. (in Russian)

11. Zhidenko AA. Psikhofiziologicheskie osnovy upravleniia dvizheniem [Psycho-physiological principles of motor control]. Visnik Chernigivs'kogo nacional'nogo pedagogichnogo universitetu. 2012;102(1):168-173. (in Russian)

12. Zaporozhanov VA, Borchinski T. Sovershenstvovanie ocenki koordinacionnykh sposobnostej zanimaiushchikhsia fizicheskimi uprazhneniiami [Perfection of coordination abilities' assessment of physical exercises' trainees]. Pedagogics, psychology, medical-biological problems of physical training and sports, 2009;9:52-55. (in Russian)

13. Kolumbet OM. Rozvitok koordinacijnikh zdibnostej molodi [Development of youth's coordination abilities], Kiev: Education Ukraine; 2014. (in Ukrainian)

14. Kozhevnikova LK. Vospitanie koordinacionnykh sposobnostej na zaniatiiakh po fizicheskomu vospitaniiu [Training of coordination abilities at physical education classes]. Physical Education of Students, 2012;1:3841. (in Russian)

15. Kurganskij AV. O vozniknovenii i koordinacii ritmicheskikh dvizhenij [On appearing and coordination of rhythmic movements]. Teoriia i praktika fizicheskoj kul'tury, 1996;11:44-49. (in Russian)

16. Litvinova OP. Vliianie ozdorovitel'noj aerobiki na razvitie dvigatel'nykh kachestv devushek 18-20 let [Influence of health related aerobics on development of motor qualities of 18-20 years' age girls]. Pedagogics, psychology, medical-biological problems of physical training and sports, 2009;10:118-122. (in Russian)

17. Liakh VI. Dvigatel'nye sposobnosti shkol'nikov [Motor abilities of schoolchildren], Moscow: Terra-Sport; 2000. (in Russian)

18. Maliar IeI, Lebid' RM. Pedagogichni umovi realizacii programi rozvitku koordinacijnikh zdibnostej [Pedagogic conditions of realization of coordination abilities' development program]. Pedagogics, psychology, medical-biological problems of physical training and sports, 2010;4:87-90. (in Ukrainian)

19. Nazarenko LD, Ignat'eva ZhA. Teoreticheskoe obosnovanie i metodika razvitiia ritmichnosti [Theoretical substantiation and methodic of rhythm's development]. Fizicheskaia kul'tura, 2000;1:45-50. (in Russian)

20. Sinajskij MM. Fiziologicheskie proiavleniia koordinacionnykh sposobnostej u sportsmenov [Physiological manifestations of sportsmen's coordination abilities]. Moscow; 2007. (in Russian)

21. Farfel' BC. Upravlenie dvizheniiami v sporte [Control over movements in sports], Moscow: Physical Culture and Sport; 1975. (in Russian)

22. Fizner LN. Upravlenie koordinaciej dvizhenij [Control over motor coordination], Moscow: Science; 1971. (in Russian)

23. Chernovsky SM, Kolumbet AN. Determination of future designers' professionally important coordination qualities. Physical education of students, 2016;2:38-44. doi:10.15561/20755279.2016.0206

24. Hirtz P. Koordinative Fahigkeiten im Schulsport [Coordinative abilities in school sports], Berlin: Volk und Wissen, Volksseigener Verlag; 1985.

25. Iermakov SS, Apanasenko GL, Bondarenko TV, Prasol SD. Physical culture is a basic instrument of culture of health. Pedagogics, psychology, medical-biological problems of physical training and sports, 2010;11:3133.

26. Iermakov SS, Ivashchenko PI, Guzov VV. Features of motivation of students to application of individual programs of physical self-preparation. Physical Education of Students, 2012;4:59-61.

27. Kolumbet AN. Influence of stimulated plasticity training method on coordination indicators of high pedagogic educational estableshments' girl students. Physical Education of Students, 2015;6:31-37. doi: $10.15561 / 20755279.2015 .0604$

28. Kolumbet AN. Dynamic of girl students' psycho-physiological indicators in process of their study at 
pedagogical higher educational establishment. Physical Education of Students, 2016;1:29-36. doi:10.15561/20755279.2016.0104

29. Kopylov YuA, Jackowska LN, Kudryavtsev MD, Kuzmin VA, Tolstopyatov IA, Iermakov SS. The concept of structure and content of health related trainings for higher educational establishments' students. Physical Education of Students, 2015;5:23-30. doi:10.15561/20755279.2015.0504

30. Lopatenko GO. Optimization of training process in pre-start fencing training on the base of out-of-training means' of mobilization orientation application. Pedagogics, psychology, medical-biological problems of physical training and sports, 2016;20(2):34-39. doi:10.15561/18189172.2016.0205

31. Marc R Lochbaum, Javan Jean-Noel, Zişan Kazak Çetinkalp, Felipe Andrés Vallejo-Reyes, Jose MenaCampbell. 2 × 2 achievement goals profiles in chilean Competitive and recreational athletes: a first look. Pedagogics, psychology, medical-biological problems of physical training and sports, 2016;1:41-46. doi:10.15561/18189172.2016.0106

32. Michael Chia, Marcus Lee. Body weight satisfaction and disordered eating among youth who are active in sport in Singapore. Pedagogics, psychology, medical-biological problems of physical training and sports, 2015, vol.4, pp. 51-58. doi:10.15561/18189172.2015.0409

33. Nishan Singh Deol, Davinder Singh. A comparative analysis of flow state in basketball performance: a psychological probe. Pedagogics, psychology, medical-biological problems of physical training and sports, 2016;1:47-51. doi:10.15561/18189172.2016.0107

34. Podrigalo LV, Iermakov SS, Alekseev AF, Rovnaya OA. Studying of interconnections of morphological functional indicators of students, who practice martial arts. Physical Education of Students, 2016;1:64-70. doi:10.15561/20755279.2016.0109

35. Skurikhina NV, Kudryavtsev MD, Kuzmin VA, Iermakov SS. Fitness yoga as modern technology of special health groups' girl students' psycho-physical condition and psycho-social health strengthening. Physical Education of Students, 2016;20(2):24-31. doi:10.15561/20755279.2016.0204 


\section{Information about the authors:}

Kolumbet A.N.; http://orcid.org/0000-0001-8775-4232; re_play@3g.ua; Kiev National University of Technology and Design; st. Nemirovich-Danchenko, 2, Kiev, 14013, Ukraine.

Dudorova L.Yu.; http://orcid.org/0000-0002-6263-4995; vykh46@i.ua; Kiev National University of Technology and Design; st. Nemirovich-Danchenko, 2, Kiev, 14013, Ukraine.

Cite this article as: Kolumbet A.N., Dudorova L.Yu. Methodic of perfection of higher pedagogical educational establishments girl students' rhythm. Physical education of students, 2016;3:4-12. doi:10.15561/20755279.2016.0301

The electronic version of this article is the complete one and can be found online at: http://www.sportpedu.org.ua/html/arhive-e.html

This is an Open Access article distributed under the terms of the Creative Commons Attribution License, which permits unrestricted use, distribution, and reproduction in any medium, provided the original work is properly cited (http://creativecommons.org/licenses/by/4.0/deed.en).

Received: 03.06.2016

Accepted: 19.06.2016; Published: 28.06.2016 